\title{
Women and Village Funds: Seizing Feminine Space in Masculine Domination of Village Development
}

\author{
R Damayanti ${ }^{1}$, A B Nugroho ${ }^{2}$, A Pratiwi ${ }^{3}$ \\ 1,2,3 Universitas Brawijaya, Malang \\ ${ }^{1}$ ratnaningsih@ub.ac.id, ${ }^{2}$ cakarief@ub.ac.id , ${ }^{3}$ ari.pratiwi@ub.ac.id
}

\begin{abstract}
On the village development which was planned and carried out by villagers there is a contestation of gender stereotype issues. Since the beginning, village development has been dominated by masculine issues due to the patriarchal culture that developed in the community. The infrastructure sector occupies the largest portion in the budget allocation of village funds. Non-infrastructure development such as health, child welfare, fulfillment of minority rights and other social issues get a small portion. Village funds are an arena for contestation on gender stereotype issues. The results of research in the management of village funds in several villages in South Minahasa Regency show that the masculine issue is still dominant in the village development sector. However, during the past year there have been efforts to fight for space for feminine issues to enter into the allocation of village funds. This effort requires women who are active in voicing their rights and village heads who are innovative and open-minded. Nevertheless, feminine issues still occupy the second place in the rural development sector. Unfortunately, this opportunity arises because development in the masculine sector has been deemed fulfilled.
\end{abstract}

Keywords: Village Funds, Gender Stereotypes, Village Development

\section{INTRODUCTION}

2019 marked the fifth year of the ongoing village development initiated by the villagers. Over the span of that time, the village has implemented developments by considering aspirations from various people according to regulations in managing village fund. Village discussion is a forum that connects village government with all groups of people, among which are the youths, people with disabilities, poverty-stricken villagers, and the women.

Over the past few years, studies on village development have attracted the attention of many scientists. Studies on village development using village funds are dominated by studies that focus on managing village funds. Before the implementation of Law No. 6 of 2014 concerning Villages, the village government never managed large funds. Pleasure in receiving village funds is reduced when the village government administratively must carry out financial accountability according to relevant regulations. Some villages in Indonesia make financial reports that are not fit with regulations and are late in reporting to the government [1]. The financial reporting process that is not fit with regulations can lead to cases of corruption of village funds [2]. This happens because the capacity of village officials in conducting financial reporting compliant with relevant regulations is still low [3]. In managing village funds, there are still many villages that do not yet have village officials that can do financial reporting [4]. 
This condition causes the need for financial reporting assistance from the district government and increasing the capacity of village officials [5].

Although the village government experienced administrative difficulties, the existence of village funds has triggered community participation. This community involvement can be seen from the village development planning process which was attended by villagers from various circles, including youth, women, the disabled, farmers/fishermen groups, and the poor population. Although community participation has not yet reached the stage of control over the ratification of development planning [6], with this community involvement, the village development budget planning process has become transparent [7]. With the disbursement of village development funded by village funds, the village community increased its welfare [8], increased its income, and increased the infrastructure and economic development of the village [9].

Instead of being used to develop village potential, village funds are widely used for infrastructure development [3]. Over the past few years, village developments were mostly focused on infrastructure provisions, for example: roads, sport facilities, village gate, and other physical developments. Undoubtedly, these provisions brought benefits for the villagers, but what about the women's needs? The emerging dominances of masculinity were found on the Teep Trans Village located in the South Minahasa Regency, North Sulawesi Province. Using case study method, this paper explains how the developments in the Teep Trans Village was dominated by masculine issues. Even though there were several spaces accommodated for feminine issues regarding village developments, those spaces were too narrow when compared to masculine issues. There needs to be intense efforts by the women to continuously voice their aspirations and to produce village development innovations out of the mainstream, which is the dominating masculine issues, for the sake of villagers' welfare. In addition to accommodating the women's need, the expansion of feminine space in rural development is a form of recognition of women's rights.

Strong efforts are needed by women to continue to voice their aspirations. Innovation in rural development is also needed which is beyond the main mainstream, that is the dominance of masculine issues. These are for the welfare of rural communities. The constraints that are often experienced by women when participating in development, especially village development, first, the patriarchal culture cohere in the community, assuming that leaders both within the household (domestic) and outside the household (public) are men. Women are only as supporters of men. Second, the level of women education in rural areas is low. This low level of education has a negative effect on the women ability to lead. Third, the marital status of women sometimes has a harmful impact on women's activities outside the home. They must ask permission from their husbands if they want to do activities outside the home. Fourth, women must share their time and workload with domestic matters. Women have to do homework such as cooking and cleaning the house as the main work. If they want to participate in the village development planning process, women will have tougher work [10].

To overcome these problems, one of the things that can be done is to carry out development planning using feminist participatory methods, namely by carrying out strategies for empowering women, diagnosing villages, and transforming villages [11]. By carrying out gender-based village development, those who will benefit from the results of this development are not only women but also marginalized groups in general who are involved in the process [11]. In addition, overcoming the problem of gender stereotyped division of work can be done by using technology. The utilization of technology in the type of work that is divided in a gendercentric way on rural communities has given positive results in the fusion of women and men 
sectors [12]. With the active participation of women in sectors that are all dominated by men, the boundaries of the areas of men and women in village development will begin to blur.

Feminine vs. masculine dichotomy in political studies has developed in the United States along with the development of women's participation in politics. Developing studies related to female candidates. Because women's participation in politics starting in the 1990s was no longer a problem, the study shifted after women candidates were elected, namely on issues that women considered to be more competent in handling than men.

Issues being classified into masculine issue or feminine issue are linked to gender or trait stereotypes adhering to men and women. Women are often considered to be compassionate, put others first, emotional, kind, gentle, submissive, polite, egalitarian [13].

Within the literatures developing in the western countries, women will be more able to resolve issues on education, fulfillment of minorities' rights, problems of people with disabilities and elderlies [14], health [15], environment and civil rights [16] than men. Men are thought to be more active, independent, decisive, aggressive, practical, assertive, hardworking, and in favor for hierarchy [13]. In regard to these traits, men will be able to overcome issues dealing with terrorism, military, security and defense [14], international trades, taxes, and agriculture [16]. However, after the 9/11 attack, female candidates are more critical of issues on terrorism and military [17].

In Indonesia, translation on the issues of gender stereotypes slightly differs from the western countries. According to LSI survey in 2019, women are seen to be more capable in handling problems regarding women issues, finances and budgeting, and health service. While men are regarded to be able to solve problems concerning defense and security, criminality eradication and law enforcement, and corruption prevention and eradication. Many consider religious matters, human right advocacy, democracy implementation, foreign affairs, economic developments, education, and environmental sustainability, are mutual issues of men and women. This paper will analyze the use of village funds using gender stereotypes applied in Indonesia.

\section{RESEARCH METHOD}

Data in this study were obtained through interviews and document analyses. Interviews were done on government officials in agencies related with social issues, which are Health Agency (Dinas Kesehatan); Regional Agency for Resident Control, Family Planning, Women Empowerment and Child Protection (DP2KBP3A); and Social Service (Dinas Sosial). Apart from the agencies related with social issues, interviews were also conducted on the personnel in the Agency for Villagers' Empowerment. On the district level, data were obtained through the officials at the community health centers (Puskesmas) at their nutrition and environment field. Meanwhile, at the village level, interviews were done on the village midwives.

Document analyses were performed on the Village Income and Expenditure Budgeting (APBDes) documents of the Teep Trans Village Government and the publication document by the Health Agency in relations to the social issues happening in South Minahasa Regency and Central Boyong Village. Aside from these documents, official documents published by the South Minahasa Regional Government such as Regency in Numbers and the amount of village fund per village were also used to complement data for this study. These documents served to provide additional information for analyses.

Collected data were then descriptively analyzed with case study type. The case taken was a case of village fund management by Teep Trans Village located at West Amurang District. The 
village fund managed in 2019 as one of the source for the village's income in the APBDes was analyzed according to the amount and percentage budgeted in that ABDes.

\section{RESULTS AND DISCUSSION}

In 2018, Indonesia's Minister of Village, Development for Disadvantaged Regions, and Transmigration issued ministerial regulation number 16 of 2018 regarding Priority for Village Fund Use for the year 2019. This regulation was supposed to be used by the "Hukum Tua" (a term for village head in South Minahasa) in managing village fund. Village fund priority in 2019 was for funding the village development activities and society empowerment that covers multiple sectors. The purpose of this priority was to increase people's living quality, to improve welfare and to alleviate poverty, as well as to improve public services at the village level (article 4)The first poetry is entitled "Tuhan Kedua" by Joko Wahono. It criticizes politicians who take their wealth and power as God. The name of God has not been mentioned in their pray, but is replaced by power, position, and money. The following quotation of poetry describes that situation.

The meaning of aforementioned people's living quality by this regulation is that the village funds are used to finance program and activity implementations in basic social service sectors which have direct impact in the increase of people's living quality. What categorize as basic village social service are first, the procurement, construction, development, and maintenance of basic facilities and infrastructures to fulfill the needs for residential environment, transportation, energy, and information and communication; second, the procurement, construction, development, and maintenance of basic service facilities and infrastructures to fulfill the needs for people's health, education, and culture; third, the procurement, construction, development, and maintenance of people's economic facilities and infrastructures, which are agriculture enterprise for food security and productive-scale agricultural economic enterprises which consists of production, distribution, and marketing aspects that are focused towards the formation and the development of village's and/or rural region's superior products; fourth, the procurement, construction, development, and maintenance of environmental facilities and infrastructures to fulfill the needs for natural disaster and social conflict preparedness, natural and social disaster management, and environmental sustainability (article 5)

The increase in public service on the village level can be achieved through society's nutritional improvement efforts as well as prevention of stunting cases. These activities consist of provision of clean water and sanitation, administration of additional and nutritious foods for children under 5 years of age, training on monitoring pregnant or breastfeeding mothers' health development, supports by integrated health centers (Posyandu) to promote regular checks for pregnant or breastfeeding mothers, developments of village's living apothecary and horticultural products to fulfill the nutritional needs for pregnant or breastfeeding mothers, development of food security in the village, and management activity of other living qualities that is in accordance with village's authority and is decided during village discussions (article 6).

In 2019, Teep Trans Village Government planned revenue from Local Own-Source Income at $\mathrm{Rp} 6.000 .000$, transfer income at $\mathrm{Rp} 1.001 .170 .000$, and other incomes at $\mathrm{Rp} 420.000$. Out of the Transfer Fund, Teep Trans Village received village fund as many as Rp 719.380.000 and $\mathrm{Rp} 281.790 .00$ from the Village Fund Allocation. Therefore, the total revenue planned by the Teep Trans Village Government amounted to Rp 1.007.590.000. This year, the Teep Trans Village Government planned their expenditures at $\mathrm{Rp} 1.061 .490 .000$. The expenditure consisted 
of administration of village government, implementation of village developments, community tutoring, community empowerment, and disaster, emergency, and urgency countermeasures.

The Village Development Field directed by the Ministry of Village must cover multiple fields, which was broken down by the government of Teep Trans Village into four development fields, namely education, health, public works and spatial design, and residential areas. The Community Tutoring Field was interpreted into youth and sports field activities. The Community Empowerment Field was interpreted into activities to improve the capacity of village officials. Teep Trans Village is located on seashore regions, where this village planned budgets for activities on disaster, emergency, and urgency countermeasures field.

Based on gender stereotypes, the four development fields implemented by the government of Teep Trans Village can be further categorized, e.g. development for education field can be considered as issues which can be handled by both women and men. Village's health issues are issues which would better be managed by women due to them being more compassionate, gentle, and lenient. Issues on public works, spatial design, and residential areas are issues which require practicality, assertiveness, and hard work, all of which intrinsically adhere to men.

Teep Trans Village budgets developments in education subfield as much as Rp 20.000 .000 or $3,18 \%$ out of the total development budget in 2019 . The health subfield received funding allocation amounting to $\mathrm{Rp} 32.705 .400$ or $5,21 \%$ out of the total development budget. Subfield of public works and spatial design received allocation as much as Rp 284.187.000 or $45,26 \%$ out of the total development budget. Subfield of residential areas received allocation as much as $\operatorname{Rp} 245.692 .000$ or $39,12 \%$ out of the total development budget.

According to an interview with officials at the community health centers (Puskesmas) of nutrition and environment field, the funding for health subfield was allocated for integrated health centers' (Posyandu) operational costs, which were the Provision of Additional Meals (PMT) and incentives for health cadres. Prior to Village Funds, the villagers were required to pay around Rp 2.000 for fees. Then, after there was Village Funds, pregnant mothers, children below 5 years, and elderlies received free treatments at the integrated health centers. Health cadres, where all of them are women, initially didn't receive any form of incentives, but now they do.

Even though there have been modifications and improvements of the health services at the village, several matters still needed to be developed further. First, the budget for health developments had very small portions, which were $5,21 \%$, compared to the total development budget. Comparing with the total village expenditures, the allocation for health subfields were only $3,1 \%$. The year 2019 is the fifth year where the village government received Village Funds, which means for the duration of 5 years, the government has not placed women-specific issues as their priority.

Second, the small amount of budget allocated for health showed the lack of accommodation for the needs of women in village discussions. Village discussions should invite women representatives. When the Village Income and Expenditure Budgeting (APBDes) only interprets women needs as integrated health centers services, then optimization for the service is imperative. Integrated health centers services do not only provide additional foods for pregnant women, children under 5 years, and elderlies, but also related to the provision of basic health service and prevention of diseases at the village.

According to the village ministerial regulation stating that in 2019, the Village Income and Expenditure Budgeting should be used for improving public services at the village, therefore all matters that may support the improvement of health service are ought to be carried out. For example, purchase of equipments to test the level of blood sugar, cholesterol, and uric acid; beds 
in the case of checkups for pregnant mothers; digital scales for accurate measures; pregnancy test tools; and so on. Village Funds should also be used to construct health service buildings at the village.

The provision of medical equipments and health service buildings can be accomplished step by step, thereby the dominance of masculine issues, such as the construction or repair of roads, renovation of water tunnels, development of gateways, and so forth, should also be balanced with feminine issues. These issues are equally important, however, in order to achieve gender-sensitive village development, balanced proportion between feminine and masculine issues is needed.

\section{CONCLUSIONS}

In essence, village developments give opportunities for women to be more involved in formulating village needs which will then be included within the Village Income and Expenditure Budgeting (APBDes). There have been some indications that women showed their involvements in village developments, but their involvements are very minimal judging from the allocated budget proportions for gender-stereotyped issues. Women at the Teep Trans Village were deemed by the village government to only be able to handle $5,21 \%$ of the total development budget. This number was very little when compared to the budget managed by men, which were $84,38 \%$.

The opportunity for women's needs to be accommodated through village developments require raising awareness for women of their needs, so that they can convey their needs during village discussions. Village head should also open up rooms for innovations for the sake of village developments to avoid monotony. Openness for feminine spaces in village developments serves no other than to increase village welfare.

\section{REFERENCES}

[1] I. Nurhakim and I. Yudianto, "Implementation of Village Fund Management in Panyirapan Village, Sukanagara Village and Soreang Village, Soreang Sub-Dstrict, Bandung Regency," J. Account. Audit. Bus., 2018.

[2] E. A. Ash-shidiqqi and H. Wibisono, "Corruption and Village: Accountability of Village Fund Management on Preventing Corruption (Problems and Challenges)," J. Indones. Leg. Stud., 2018.

[3] A. R. Ramly, W. Wahyuddin, J. Mursyida, and M. Mawardati, "The Implementation of Village Fund Policy in Improving Economy of Village Society,” J. Ilm. Peuradeun, 2018.

[4] I. Meutia and L. Liliana, "The Management of Village Fund Finances," J. Din. Akunt., 2018.

[5] N. Azlina, A. Hasan, Desmiyawati, and I. Muda, "The effectiveness of village fund management (case study at villages in coastal areas in Riau)," Int. J. Econ. Res., 2017.

[6] B. et. a. Siswanto, "Community Participation and Stakeholders in Village Fund Management,” Econ. Sustain. Dev., vol. 8, no. 20, pp. 42-47, 2017.

[7] Y. G. Tulis, I. Utami, and A. N. S. Hapsari, "Village Fund Management Transparency: A Lesson Learned," J. Account. Strateg. Financ., 2018.

[8] S. Kurniawati, "The Influence of Village Fund Towards Achievement of Society's Welfare at Wukirsari Village, Yogyakarta," FALAH J. Ekon. Syariah, 2018.

[9] F. A. Nasution, Erlina, and Rujiman, "The Role of Village Funds to the Development 
Area in the Sub- District of West Bilah, Labuhanbatu Regency, North Sumatera, Indonesia," Int. J. Progress. Sci. Technol., 2017.

[10] S. Opare, "Engaging women in community decision-making processes in rural Ghana: Problems and prospects," Dev. Pract., 2005.

[11] S. Ortiz Escalante and B. Gutiérrez Valdivia, "Planning from below: using feminist participatory methods to increase women's participation in urban planning," Gend. Dev., 2015.

[12] P. P. Otte, L. D. Tivana, R. Phinney, R. Bernardo, and H. Davidsson, "The importance of gender roles and relations in rural agricultural technology development: a case study on solar fruit drying in Mozambique," Gend. Technol. Dev., 2018.

[13] N. J. G. Winter, "Masculine Republicans and Feminine Democrats: Gender and Americans' Explicit and Implicit Images of the Political Parties," Polit. Behav., 2010.

[14] S. M. Rosenwasser, R. R. Rogers, S. Fling, K. Silvers-Pickens, and J. Butemeyer, "Attitudes toward Women and Men in Politics: Perceived Male and Female Candidate Competencies and Participant Personality Characteristics," Polit. Psychol., 1987.

[15] K. Dolan, "The impact of gender stereotyped evaluations on support for women candidates," Polit. Behav., 2010.

[16] D. Alexander and K. Andersen, "Gender as a Factor in the Attribution of Leadership Traits," Polit. Res. Q., 1993.

[17] J. L. Lawless, "Women, war, and winning elections: Gender stereotyping in the postSeptember 11th era," Political Research Quarterly. 2004. 